\title{
The Role of Antioxidants in Cerebellar Development. A Review of Literature
}

\author{
Rol de los Antioxidantes en el Desarrollo del Cerebelo. Una Revisión de la Literatura
}

\author{
I. O. Imosemi
}

IMOSEMI, I. O. The role of antioxidants in cerebellar development. A review of literature. Int. J. Morphol., 31(1):203-210, 2013.

SUMMARY: Developmental pathologies may result from endogenous or xenobiotic-enhanced formation of reacting oxygen species (ROS), which oxidatively damage cellular macromolecules and/or alter signal transduction, and that the embryonic processes regulating the balance of ROS formation, oxidative DNA damage and repair, and ROS-mediated signal transduction may be important determinants of teratological risk. ROS can oxidize molecular targets such as DNA, protein, lipid in a process called oxidative stress resulting in cellular dysfunction and in utero death or teratogenicity. This review, consisting of literature search of journals and chapters in books aims at highlighting the importance of the cerebellum in controlling various motor activities in the body, as well as substances affecting cerebellar development with a view of providing an insight to the role antioxidants play in cerebellar development. It is interesting to note that the developing brain (especially the cerebellum, cerebrum and hippocampus) is highly vulnerable to the deleterious effects of ROS. Studies have shown that exposure to oxidants in the first trimester is associated with an increased risk of major congenital anomalies, as most vital organs in the body develop and some become functional within this period in offspring. Antioxidants may prevent oxidative damage in degenerative diseases including ageing, cardiovascular diseases, cancer, Alzheimer's disease, stroke and Parkinson's disease as such play a critical role in wellness and health maintenance.

KEY WORDS: Cerebellar development; Reacting oxygen species; Oxidative stress; Antioxidants.

\section{INTRODUCTION}

The consumption of some drugs and chemical substances at various doses could cause malformations in certain developing body organs especially when used during critical periods of development. Such malformations could reflect in the gross and microscopic appearances of affected organs in the mature organisms (Moore \& Persaud, 1998). The critical stages of development at which such malformations occur in mammals correspond to the pre-natal and early postnatal lives. In the former circumstance, these substances when consumed by the mother, affect the embryos or foetus only if they cross the blood placental barrier. In the latter circumstance, the substances need to have been administered directly to the neonates or suckled in the breast milk in early post-natal life for them to affect development (Moore \& Persaud).

The cerebellum is a highly organized structure in which the Purkinje cells $(\mathrm{Pc})$ are the sole output of the cerebellar cortex (Altman, 1969, 1972a, 1972b, 1972c), and it is one of the first structure of the brain to differentiate, however, it achieves its mature configuration many months after birth (Wang \& Zoghbi, 2001; Bouet et al., 2005). For this reason, the cerebellum is especially vulnerable to developmental irregularities on exposure to oxidants which generate free radicals resulting in oxidative stress (Wang \& Zoghbi; Kern \& Jones, 2006). Oxidative stress occurs due to an imbalance in pro-oxidant and antioxidant levels. Scientific evidence suggests that under oxidative stress conditions, oxygen radicals such as superoxide anion $\left(\mathrm{O}_{2}\right.$. $)$, hydroxyl radical $(. \mathrm{OH})$ and hydrogen peroxide $\left(\mathrm{H}_{2} \mathrm{O}_{2}\right)$ are produced in biological systems which causes cellular dysfunction and in utero death or teratogenicity.

To prevent free radical-induced cellular damage, the human body has an intrinsic defense mechanism called the antioxidants system. This system includes, endogenous antioxidant enzymes such as superoxide dismutase (SOD), catalase (CAT), glutathione peroxidase (GSHPx) and glutathione reductase (GSSGR), low molecular antioxidants such as glutathione (GSH) and plasma proteins, and exogenous antioxidants such as vitamins C, E and b-carotene (Zablocka \& Janusz, 2008). Glutathione plays a key role in 
maintaining the physiological balance between prooxidant and antioxidants. Plasma proteins, vitamins $\mathrm{C}$ and $\mathrm{E}$ can inhibit ROS generation and lipid peroxidation by chelating free transition metals such as copper and iron (Zablocka \& Janusz). A number of clinical studies suggest that the antioxidants in fruits and vegetable are key factors in reducing the incidence of chronic diseases including heart disease and some cancers (Salah et al., 1995; Gerber et al., 2002; Kris-Etherton et al., 2002; Serafini et al., 2002). This review aims at highlighting the importance of the cerebellum in controlling various motor activities in the body, as well as substances affecting cerebellar development with a view of providing an insight in the role antioxidants play in cerebellar development.

The Cerebellum. The cerebellum phylogenetically is derived from the metencephalon, a subdivision of the rhombencephalon and embryologically from the dorsal thickenings of the alar plates. These thickenings bend medially forming the rhombic lips. Below the mesencephalon, the rhombic lips approach each other in the midline forming the cerebellar plates. This plate with further development shows a small midline portion called the vermis and two lateral portions called the cerebellar hemispheres. A transverse fissure soon separates the nodule from the vermis and the flocculus from the cerebellar hemispheres (Langman et al., 1972). Since the cerebellum is a thickening in the dorsal wall of the neural tube (not an evagination), it has no ventricular cavity even though it overlies the fourth ventricle (DeMyer, 1988).

At first, the developing cerebellum (early cerebellar rudiment) consists of a pseudostratified epithelium which differentiates into an inner neuroepithelial (ventricular), mantle (intermediate) and marginal (outer) layers (Williams et al., 1989). Cells of the neuroepithelial layer migrate to the surface to form the transient germinal layer called the external granular layer (EGL) (Rakic \& Sidman, 1970). Rapid cell division as evidenced by DNA synthesis occurs in the EGL leading to the production of the various types of cells in the cerebellar cortex. These cells migrate towards the deeper differentiating Purkinje cells (Pc), which develop from the definitive germinal layer, giving rise to the Golgi type II, granule, basket and outer stellate cells (Langman et al.).

In rats, the cerebellar anlage appears by day 8 of development. Most Purkinje cells originate in the cerebellar anlage by day 15 of development (Das \& Nornes, 1972; Schultz et al., 1974; Altman \& Bayer, 1978). The Purkinje cells migrate through the deep nuclear neuropil and at birth, accumulate in a layer deep to the extarnal granular layer (EGL) (Altman \& Bayer). By 3-4 days post-partum,
Purkinje cells have assembled into a mono layer (Altman \& Winfree, 1977). Climbing fibres which are excitatory fibres from the inferior olivary nucleus become functional by day 3 post-partum (Crepel, 1971) and engage many Purkinje cells at this time (Mariani, 1982). By day 15 postpartum, the adult one-to-one relationship between the Purkinje cells and climbing fibres is achieved. The Purkinje cell dendritic tree is very well suited to dendritic field analysis (Berry et al., 1972) and under the electron microscope, it has been found that the Purkinje cell dendritic tree is innervated by well defined fibre systems which converge on the different parts of the network. Climbing fibres from the inferior olivary nucleus innervate the "smooth" proximal branches, parallel fibres engage spines on the distal branches and monoaminergic fibres ramify about the soma and proximal dendrites (Palay \& Chan-Palay, 1974).

The Purkinje cells produce selective inhibition in the deep nuclei, in the white matter of the cerebellum via their neurotransmitter, which is Gamma Amino Butyric Acid (GABA). They are also capable of inhibiting neighbouring Purkinje cells. Other neurotransmitters that have been located in the neurons and fibres of the cerebellar cortex include motilin, taurin, emkaphalin, glutamate and aspartate. Some cholinergic, noradrenergic and serotonergic fibres are also present (Singh, 1997).

The cerebellum functions in controlling various motor activities in the brain. It also controls the range, distance and amplitude of voluntary muscles activity. It is the integrating centre for willed muscular movements and posture. By implication, the main function of the cerebellum is to co-ordinate the sequence and the strength of muscular contractions during posture and voluntary movements (DeMyer). It controls proprioceptive impulses from joint pain and Golgi tendons. Because the cerebellum has connections with the vestibular apparatus, it functions in the maintenance of balance. It plays an important role in the production of smooth words and for precise and intrinsic movements (Hendelman, 2000).

The cerebellum receives blood from the following arteries:

a) Posterior inferior cerebellar artery which is the largest branch from the vertebral artery. It supplies the inferior cerebellar peduncle, posterior and inferior parts of the cerebellum.

b) Anterior inferior cerebellar artery which is the first branch of the basilar artery. It supplies the middle cerebellar peduncle, deep cerebellar nuclei and the anterior and inferior parts of the cerebellum. 
c) Superior cerebellar artery which is the penultimate branch of the basilar artery. It supplies the superior cerebellar peduncle, deep cerebellar nuclei and the superior surface of the cerebellum (Montemurro \& Bruni, 1988).

The venous drainage of the cerebellum is from the surface of the cerebellum into the closest available dural venous sinus. The superior and posterior surfaces drain into the straight and transverse sinuses. The inferior surface drains into the inferior petrosal, sigmoid and occipital sinuses. The superior vermis drains into the great cerebral vein of Galen at its entrance into the straight sinus (McMinn, 1995).

The cerebrospinal fluid (CSF) spaces found in and around the cerebellum are the cerebellomedullary, pontine and superior cisterns. The CSF from the fourth ventricle enters the subarachnoid space through the median and lateral apertures (foramina of Magendie and Luschka respectively) where it collects in the cerebellomedullary and pontine cisterns. From these cisterns, the CSF passes inferiorly into the spinal subarachnoid space around the spinal cord and behind and superiorly over the cerebellum. The CSF is absorbed into the venous system through the arachnoid villi, which is a protrusion of the arachnoid matter into the dural venous sinuses (Moore, 1985).

Substances affecting the developing cerebellum. The developing cerebellum, like the entire nervous system, is known to be affected by such substances as caffeine, theobromine, theophylline as well as such fruits as kola nut (Kimel et al., 1984; Abdi et al., 1993; Wilkinson \& Pollard, 1993), nutritional deficiency (Clark et al.), cytotoxic agents (Singh et al., 1973), cyanide (Patel et al., 1991; Pavlakovic et al., 1994; Malomo et al., 2004; Imosemi et al., 2005), irradiation, (Doughty et al., 1999; Inuoye et al., 1999), some central nervous system depressants, such as pentobarbital and cyclophosphamide, an alkylating agent (Maslinka, 1986), alcohol (West et al., 1990), and anticonvulsant drugs, such as valproic acid, carbamazepine, phenytoin and phenobarbital (Ornoy, 2003). Anticonvulsant drugs for example, have been found to induce neurotoxicity by generating free radicals resulting in oxidative stress which leads to cellular damage and dysfunction.

Phenytoin administration has been reported to be associated with cerebellar atrophy and persistent cerebellar ataxia with clinical manifestation presenting as confusion, slurred speech and nastagmus following acute and longterm intoxication (Imamura et al., 1992; Ney et al., 1994) and temporal cerebellar atrophy following phenytoin therapy (Guerrero et al., 1997).
The central nervous system has been found by Altman (1987) to be the target of harmful environmental agents which results in behavioural abnormalities in humans without any quantitatively evident neuropathy. This he termed microneuronal hypoplasia, which is a retardation of brain development characterized by a quantitative reduction in the normal population of late generated, short axoned neurons in specific brain regions. Correlative descriptive and experimental neurogenetic studies in the rats have established that the cerebellar granule cells and a very high population of hippocampal granule cells are produced post-natally.

Focal low dose of X-irradiation either of the cerebellum or hippocampus after birth, selectively interfere with the acquisition of the full compliment of the granule cell resulting in microneuronal hypoplasia (Altman, 1987), there was abnormal neural organization in which immature characteristics, such as distorted arrangement of the glomeruli and imcomplete circuitory formation are retained in the adult rat. Such rats were found to be unable to accurately learn spartial task and suffered memory impairment (Le Marec et al., 1997). Partial destruction of granule cell population as well as a significant increase in Purkinje cell dendritic growth in young Lurcher mice exposed to X-irradiation was also reported (Doughty et al.).

The influence, individually, or in combination of certain central nervous system depressants (pentobarbital, verapamil, cyclosphophamide and alcohol) and calcium ions on rat cerebellar cyclic guanicil monophosphate (cGMP) were studied. The result revealed an increasing dose of pentobarbital with verapamil enhanced the inhibition of the cerebellar cGMP (Szot et al., 1985). The secondary messenger cGMP regulates multiple aspects of structural, developmental andphysical functions in the developing nervous system (Currie et al., 2006).

Neuronal death is one of the most serious consequences of alcohol exposure during development. It has been demonstrated in both human and animal models that alcohol produces both physical and behavioural defects and that heavy pre-natal alcohol exposure can lead to a distinct pattern of birth defects termed foetal alcohol syndrome (FAS) (Roecbuck et al., 1998). There is a wide and devastating influence of alcohol on the developing brain, although for the most part, no specific pattern of brain malformation has been identified. More recent magnetic resonance imaging studies particularly when combined with quantitative studies have indicated that specific brain areas, such as the basal nuclei, corpus callosum and parts of the cerebellum might be especially susceptible to alcohol teratogenic effects (Roecbuck et al.). 
West et al., also studied the effect of alcohol exposure in neonatal brain and found that the Purkinje cells that are in the process of extending dendrites are more vulnerable to alcohol than lobule containing Purkinje cells that mature later. Alcohol exposure during brain development may be producing neuron attrition in multiple ways including, disruption of membrane integrity, inhibition of protein synthesis or other alterations such as lipid solubility, or bydisruption of cytoskeletal elements.

Hetzel et al., (1988) reported the effect of severe iodine deficiency on brain development using animal models, including rat, marmoset monkey and sheep. These models are all characterized by the production of severe maternal and fetal hypothyroidism, which is associated with effects of the maturation of the cerebral cortex and cerebellum. There was reduced weight, number of cells as indicated by reduced DNA, and reduced cell acquisition in the cerebellum.

13-cis-retinoic acid, an analogue of vitamin A, has some teratogenic effect in humans and animals. In a study on the Macaque, it was reported that malformations were restricted to the cerebellum and internal ear. Embryo lethality were most prevalent when single doses of 13-cisretinoic acid were administered during pre and early organogenesis (Hendrickx et al., 1998).

Cyanide has also been reported to have teratogenic effect in the developing cerebellum in rats, causing delayed maturation of the cells of the external granular layer (EGL), reduction in the molecular layer (ML) (Malomo et al.,), reduction in the weight, maximum side-to-side dimension and length of the vermis of the cerebellum (Imosemi et al., 2005).

Several studies on humans (pre- and post-natal periods) provide data that carbon monoxide and cigarette smoke affects normal growth and development (Montagnani et al., 1996; McGregor et al., 1998; Mereu et al., 2000). Carbon monoxide readily crosses the placenta and binds to foetal haemoglobin (Neubeger et al., 1982; Montagnani et al.; Mereu et al.; Lavezzi et al., 2005). Gestational exposure to carbon monoxide impairs vascular reactivity in rat offspring atdifferent stages of neurogenesis (Di Giovanni et al.). The developing central nervous system and the peripheral nervous system are extremely susceptible to the reduction of oxygen availability produced by carbon monoxide exposure (Mactutus \& Fechter, 1984), and both neurobehavioural and neurochemical alterations have been found in male rat offspring exposed to low levels of carbon monoxide during gestation (Di Giovanni et al.; Cagiano et al., 1998).
Relatively mild pre-natal exposure of rats to carbon monoxide has been reported to alter certain biochemical and functional integrity in the central nervous system post-natally. Such alterations include: change in the content of some neurotransmitters in the brain stem and cerebellum (Storm \& Fechter, 1985; Storm et al., 1986), dysfunction of the dopaminergic mesolimbic system (Cagiano et al.,), impairment of the maintenance of long-term potentiation associated with a decreased activity of the enzymes haem oxygenase-2 (HO-2) and nitric oxide synthase (NOS) in the hippocampus (Mereu et al.).

The developing cerebellum is highly susceptible to pre-natal carbon monoxide exposure at low concentration (Storm \& Fechter; Storm et al.). Studies on animal models have shown that Purkinje cells are vulnerable to ischaenia, hypoxia, excitotoxicity, oxidative stress and exposure to different types of chemicals (Kern \& Jones). It has been well documented that prenatal carbon monoxide exposure has selective effects on the different cell types (Benagiano et al., 2005). Benagiano et al., found that Purkinje and Golgi type II neurons did not appear to be susceptible, unlike the post-natally generated stellate and basket neurons. For the above reasons, it is possible that very mild chronic exposure to carbon monoxide may affect cerebellar neurons.

Role of antioxidants in cerebellar development. The balance of ROS can be termed as the "balance of creation and destruction". Under normal circumstances, there is an appropriate balance between proxidant and antioxidant. A shift in the levels of ROS towards prooxidants in developing brain can generate free radicals which in turn can induce an oxidative stress on the cerebellum and may result in cerebellar dysfunction.

Humans have evolved with antioxidant defense systems to protect against free radicals (Pier-Giorgio, 1999). These systems include some antioxidants produced in the body (endogenous) and others obtained from the diet (exogenous). Due to the imcomplete efficiency of the endogenous defense systems and the existence of some pathophysiological situations (cigarette smoke, air pollutants, ultraviolet radiation and xenobiotics) in which ROS are produced in excess and at the wrong time and place, dietary antioxidants are needed for diminishing the cumulative effects of oxidative damage over the life-span (Wayner et al., 1987; Halliwel, 1994). Well established antioxidants derived from diets are vitamins $\mathrm{C}$ and $\mathrm{E}$, and carotenoids, which have been studied extensively (Sies, 1986).

Beside these antioxidant vitamins, other substances in plants might account for at least part of the health benefits associated with vegetables and fruits consumption. A number 
of clinical studies suggest that the antioxidants in fruits and vegetables are key factors in reducing the incidence of chronic diseases including heart disease and some cancers (Salah et al.; Gerber et al.; Kris-Etherton et al.; Serafini et al.).

Over the past decade, evidence has been accumulated that polyphenols are important class of defense antioxidants. These compounds are widespread virtually in all plant foods, often at high level and include phenols, phenolic acid, flavonoids, tannins and ligans. Antioxidants are reported to boost the function of immune cells against homeostatic disturbance and their free radical scavenging activity has been substantially investigated (De la Fuente \& Victor, 2000).

Pre- and post-natal exposure of rat to different toxic substances has been shown to have deleterious effects on the developing cerebellum. In an experiment using animal model, ethanol was found to impair neuronal survival in neonatal rat cerebellar granule cell by increasing generation of free radicals and expression of apoptosis-related proteins. However, in the presence of exogenous antioxidant, vitamin E, neuronal survival level was enhanced (Heaton et al., 2004).

Also pycnogenol, a patented combination of bioflavonoids extracted from the bark of French maritime pine (Pinus maritima) protected the developing cerebellar granule cell from ethanol neurotoxicity by inhibting apoptosis and necrosis of the developing neurons, and oxidant scavenging and modulation of endogenous, cellular proteins (Silar-Marsiglio et al., 2005).

Impaired antioxidant defense mechanisms and oxidative stress are implicated in the pathogenesis of arsenic toxicity in developing cerebellum, cerebral cortex, hypothalamus and hippocampus. However, administration of a-lipoic acid which has been shown to have substantial antioxidant properties overcame arsenic-induced deficits in the antioxidant enzyme activities and increase in oxidant production and lipid peroxidation level in the brain regions (Shila et al., 2005).

Glial reactivity in the developing hippocampus, cerebellum and cerebral cortex of streptozotocin-induced diabetic rats was studied. The metabolic and oxidative insults resulted in rapid change in the glial cells. Administration of melatonin, an antioxidant, prevented the upregulation of glial fibrillary acidic protein (GFAP) in all the brain regions studied. The result suggested that diabetes causes increased glial reactivity possibly due to elevated oxidative stress, and that administration of melatonin represented an achievable adjunct for preventing gliosis (Baydas et al., 2003).
Melatonin was also reported to protect the developing cerebellum, cerebral cortex and hippocampus against toluenecontaining thinner intoxication by reducing reactive gliosis (Baydas et al.). In the research, melatonin treatment provided the protection by increasing the survival of glial cells possibly by directly scavenging reactive oxygen species and by indirectly augmenting their antioxidant capacity. Dare et al. (2000) reported that developing cerebellar granule cells were protected by antioxidants J118 and 17, b-estradiol from methylmercury-induced apoptotic cell death.

Calotropis procera leaf extract has been reported to posses antioxidant activity by increasing the glutathione levels and decreasing the rate at which lipid peroxidation occurred in the developing cerebellum (Imosemi et al., 2010), preventing delayed maturation of cells of the cerebellar cortex and depletion of Purkinje cells of the developing cerebellum in phenytoin-induced oxidative stress (Imosemi \& Osinubi, 2011). And that the antioxidant property of Calotropis procera was comparable to standard antioxidants, vitamins $\mathrm{C}$ and $\mathrm{E}$.

Ginkgo biloba extract reported to have antioxidant activity, protected the developing cerebellar cells from hydrogen peroxide-induced oxidative damage by preventing the cells from apoptotic cell death and effectively attenuated oxidative damage. The result of the research suggested that the extract might be used as a potential drug for neuronal diseases associated with the excessive production of reactive oxygen species (Wei et al., 2000).

CONCLUSION. Considering the important functions of the cerebellum in controlling various motor activities, exposure of the developing cerebellum to oxidants may result in developmental irregularities induced by embryonic hypoxia with vascular necrosis and tissue disruption as a result of ischaemic damage. However, antioxidants may prevent oxidative damage in cerebellar development, as such play a critical role in wellness and health maintenance.

IMOSEMI, I. O. Rol de los antioxidantes en el desarrollo del cerebelo. Una revisión de la literatura. Int. J. Morphol., 31(1):203$210,2013$.

RESUMEN: Las patologías del desarrollo pueden resultar de la formación endógena o xenobiótica de especies reactivas de oxígeno (ROS), que dañan oxidativamente macromoléculas celulares y/o alteran la transducción de señales, y los procesos embrionarios que regulan el equilibrio de la formación de ROS, daño oxidativo y reparación del ADN; la transducción de señales mediada por ROS pueden ser determinantes e importantes del riesgo teratológico. Las ROS pueden oxidar blancos moleculares como el ADN, proteínas y lípidos en un proceso llamado estrés oxidativo 
que resulta en disfunción celular y muerte intrauterina o teratogenicidad. Esta revisión consiste en la búsqueda bibliográfica de artículos y capítulos de libros con el objetivo de destacar la importancia del cerebelo en el control de diversas actividades motoras del cuerpo, así como las sustancias que afectan el desarrollo de él con el fin de proporcionar una visión del rol que juegan los antioxidantes en el desarrollo del cerebelo. Es interesante observar que el encéfalo en desarrollo (especialmente el cerebelo, cerebro e hipocampo) son altamente vulnerables a los efectos deletéreos de las ROS. Se ha demostrado que la exposición a oxidantes en el primer trimestre de embarazo se asocia con un mayor riesgo de anomalías congénitas graves, como la mayoría de los órganos vitales del cuerpo en desarrollo y algunos se vuelven funcionales dentro de este período en la descendencia. Los antioxidantes pueden prevenir el daño oxidativo en enfermedades degenerativas incluyendo envejecimiento, enfermedades cardiovasculares, cáncer, enfermedad de Alzheimer, accidente cerebrovascular y enfermedad de Parkinson, y desempeñan un rol crítico en el mantenimiento de la salud y el bienestar.

PALABRAS CLAVE: Desarrollo cerebelar; Especies reactivas de oxígeno; Estrés oxidativo; Antioxidantes.

\section{REFERENCES}

Abdi, F. B.; Pollard, J. \& Wilkison, J. M. Placental transfer and foetal disposition of caffeine and its metabolites in twenty day pregnant rats. A function of dose. Xenobiotica, 23(4):449-56, 1993.

Altman, J. Autoradiographic and histologic studies of postnatal neurogenesis III. Dating the time of production and onset of differentiation of cerebellar microneurons in the rat. J. Comp. Neurol., 136(3):269-94, 1969.

Altman, J. Postnatal development of the cerebellar cortex in rat I. The external germinal layer and the transitional molecular layer. J. Comp. Neurol., 145(3):353-97, 1972a.

Altman, J. Postnatal development of the cerebellar cortex in rat II. Phases in the maturation of Purkinje cells and the molecular layer. J. Comp. Neurol., 145(4):399-464, 1972 b.

Altman, J. Postnatal development of the cerebellar cortex in rat III. Maturation of the components of the granular layer. J. Comp. Neurol., 145(4):465-513, 1972c.

Altman, J. Morphological and behavioural markers of environmentally induced retardation of brain development: An animal model. Environ. Health Perspect., 74:153-68, 1987.

Altman, J. \& Bayer, S. A. Time of origin and distribution of a new cell type in the rat cerebellar cortex. Exp. Brain Res., 29(2):26574, 1977.

Altman, J. \& Winfree, A. Postnatal development of the cerebellar cortex in rat. V. spartial organization of Purkinje cell perikaryon. J. Comp. Neurol., 171(1):1-16, 1977.
Baydas, G.; Reiter, R. J.; Yasar, A.; Tuzeu, M.; Akdemir, I. \& Nedzvetskii, V. S. Melatonin reduces glial reactivity in the hippocampus, cortex and cerebellum of streptozotocin-induced diabetic rats. Free Radi. Biol. Med., 35(7):797-804, 2003.

Benagiano, V.; Lorusso, L.; Coluccia, A.; Tarullo, A.; Flace, P.; Girolamo, F.; et al. Glutamic acid decarboxylase and GABA immunoreactivities in the cerebellar cortex of adult rat after prenatal exposure to a low concentration of carbon monoxide. Neuroscience, 135(3):897-905, 2005.

Berry, M.; Hollingworth, T.; Flinn, R. M. \& Anderson, E. M. Dendritic field analysis--a reappraisal. TIT J. Life Sci., 2(4):12940, 1972.

Bouet, V.; Dijk, F.; Ijkema-Paassen, J.; Wubbles, R. J.; Want, J. J. \& Gramsbergen, A. Early hypergravity exposure effects calbindinD28K and inositol-3-phosphate expression in Purkinje cells. Neurosci. Lett., 382(1-2):10-5, 2005.

Cagiano, R.; Ancona, D.; Cassano, T.; Tattli, M.; Trabace, L. \& Cuomo, V. Effects of prenatal exposure to low concentration of carbonmonoxide on sexual behaviour and mesolimbic dopaminergic function in rat offspring. Br. J. Pharmacol., 125(4):909-15, 1998.

Clark, G. M.; Zahemh, S.; Van Marthers, E.; Granel, L. \& Kragger, L. The effects of prenatal malnutrition on dimensions of cerebral cortex. Brain Res., 54:397-402, 1973.

Crepel, F. Maturation of climbing fibre responses in the rat. Brain Res., 35:272-6, 1971.

Currie, D. A.; De Vente, J. \& Moody, W. J. Developmental appearance of cGMP production and nitric oxide responsiveness in embryonic mouse cortex and striatum. Dev. Dyn., 235(6):166877, 2006.

Dare, E.; Gotz, M. E.; Zhivotovsky, B.; Manzo, L. \& Ceccatelli, S. Antioxidants J811 and 17 beta-estradiol protect cerebellar granule cells from methylmercury-induced apoptotic cell death. $J$. Neurosci. Res., 62(4):557-65, 2000.

Das, G. D. \& Nornes, H. O. Neurogenesis in the cerebellum of the rat: an autoradiographic study. Z. Anat. Entwicklungsgesch., 138(2):155-65, 1972.

De la Fuente, M. \& Victor, M. Antioxidants as modulators of immune function. Immunol. Cell. Biol., 78(1):49-54, 2000.

DeMyer, W. Neuroanatomy, National Medical Series for Independent Study. Philadelphia, Harwal Publishing, 1988. pp.187-206.

Di Giovanni, V.; Cagiano, R.; De Silva, M. A.; Giustino, A.; Lacomba, C.; Renna, G. \& Cuomo, V. Neurobehavioural changes produced in rats by prenatal exposure to carbon monoxide. Brain Res., 616(1-2):126-31, 1993.

Doughty, M. L.; Delhaye-Bouchaud, N. \& Mariani, J. Quantitative analysis of cerebellar lobulation in normal and agranular rats. $J$. Comp. Neurol., 399(3):306-20, 1999. 
Gerber, M.; Boutron-Ruault, M. C.; Hercberg, S.; Riboli, E.; Scalbert, A. \& Siess, M. H. Food and cancer: state of the art about the protective effect of fruits and vegetables. Bull. Cancer, 89(3):293$312,2002$.

Guerrero, A. L.; Paniagua, J. A.; Diaz Caseajo, P.; Cacho, J.; Arias, P. \& Martin, J. Temporal cerebellar atrophy following phenytoin therapy. Neuroglia, 121(6):259-61, 1997.

Halliwell, B. Free radicals, antioxidants, and human disease: curiosity, cause, or consequence? Lancet, 344(8924):721-4, 1994.

Heaton, H. B.; Madorsky, I.; Paiva, M. \& Siler-Marsiglio, K. I. Vitamin E amelioration of ethanol neurotoxicity involves modulation of apoptosis-related protein levels in neonatal rat cerebellar granule cells. Brain Res. Dev. Brain Res., 150(2):117-24, 2004.

Hendelman, W. J. Atlas of Functional Neuroanatomy. Boca Raton, CRC Press LLC, 2000. pp.126-34.

Hendrickx, A. G.; Tzimas, G.; Korte, R. \& Hummler, H. Retinoid teratogenicity in the Macaque. J. Med. Primatol., 27(6):310-8, 1998.

Hetzel, B. S.; Chavadej, J. \& Potter, B. J. The brain in iodine deficiency. Neuropathol. Appl. Neurobiol., 14(2):93-104, 1988.

Imamura, T.; Ejima, A.; Sahara, M.; Saito, H. \& Tsuburaya, K. Cerebellar atrophy and persistent cerebellar ataxia after acute intoxication of phenytoin. No To Shinkei, 44(2):149-53, 1992.

Imosemi, I. O.; Malomo, A. O.; Oladejo, O. W.; Osuagwu, F. C.; Ekpo, O. E.; Akang, E. E. \& Shokunbi, M. T. Grossmorphometric studies on the effect of cyanide on the developing cerebellum of Wistar rat (Rattus Novegicus). Afr. J. Med. Med. Sci., 34(1):5963, 2005.

Imosemi, I. O.; Osinubi, A. A.; Saalu, L. C. \& Olagunju, J. A. Phenytoininduced toxicity in the post-natal cerebellar development in rat: effect of Calotropis procera on selective biochemical and haematological variables. Int. J. Biol. Chem. Sci., 4(6):2387-96, 2010.

Imosemi, I. O. \& Osinubi, A. A. Phenytoin-induced toxicity in the postnatal cerebellar development in rats, Effect of Calotropis procera on histomorphometric parameters. Int. J. Morphol., 29(2):331-8, 2011.

Inuoye, M.; Hayasaka, S.; Takahashi, S.; Kubota, Y. \& Murata, Y. A comparison of the effects between accelerated heavy ion irradiation and $\mathrm{X}$-irradiation on the development of rat cerebellum. Environ. Med., 43(1):69-71, 1999.

Kern, J. K. \& Jones, A. M. Evidence of toxicity, oxidative stress, and neuronal insult in Autism. J. Toxicol. Environ. Health B Crit. Rev., 9(6):485-99, 2006.

Kimel, C. A.; Kimmel, G. L.; White, C. G.; Gafton, T. E.; Young, J. F. \& Nelson, G. J. Blood flow changes and conceptual development in pregnant rats in response to caffeine. Fundam. Appl. Toxicol., 4(2 Pt. 1):240-7, 1984
Kris-Etherton, P. M.; Hecker, K. D.; Bonanome, A.; Coval, S. M.; Binkoski, A. E.; Hilpert, K. F.; et al. Bioactive compounds in foods: their role in the prevention of cardiovascular disease and cancer. Am. J. Med., 113 Suppl 9B:71S-88S, 2002.

Langman, J.; Shimada, M. \& Roider, P. Floxuridine and its influence of postnatal cerebellar development. Pediatr. Res., 6(10):758-64, 1972.

Lavezzi, A. M.; Ottaviani, G. \& Matturi, L. Adverse effects of prenatal tobacco smoke exposure on biological parameters of the developing brainstem. Neurobiol. Dis., 20(2):601-7, 2005.

Le Marec, N.; Dahhoaoni, M.; Stelz, T.; Bakalian, A.; DelhayeBouchaud, N.; Caston, J.; et al. Effects of cerebellar granule cell depletion on spartial learning and memory in an advoidance oconditionimg task: Studies in postnatally X-irradiated rats. Brain Res. Dev. Brain Res., 99(1):20-8, 1997.

Mactutus, M. \& Fechter, L. D. Prenatal carbonmonoxide exposure: learning and memory deficits. Science, 223(4634):409-11, 1984.

Malomo, A. O.; Imosemi, I. O.; Osuagwu, F. C.; Oladejo, O. W.; Akang, E. E. \& Shokunbi, M. T. Histomorphometric studies on the effect of cyanide consumption on the developing cerebellum of Wistar rat (Rattus Novegicus). West Afr. J. Med., 23(4):323-8, 2004.

Mariani, J. Extent of multiple innervation of Purkinje cells by climbing fibers in the olivocerebellar system of weaver, reeler, and staggerer mutant mice. J. Neurobiol., 13(2):119-26, 1982.

Maslinska, D. Effect of alkylating drugs on rat cerebellum. Folia Histochem. Cytobiol., 24(1):47-52, 1986.

McGregor, H. P.; Westcott, K. \& Walker, D. W. The effect of prenatal exposure to carbonmonoxide on breathing and growth of the newborn guinea pig. Paediatr. Res., 43(1):126-31, 1998.

McMinn, R. H. M. The cerebellum. Last's Anatomy. Regional and Applied Anatomy. $9^{\text {th }}$ ed. Edinburgh, Churchill Livingstone, 1995.

Mereu, G.; Cammalleri, M.; Fà, M.; Francesconi, W.; Saba, P.; Tattoli, M.; et al. Prenatal exposure to a low concentration of carbon monoxide disrupts hippocampal long-term potentiation in rat offspring. J. Pharmacol. Exp. Ther, 294(2):728-34, 2000.

Montagnani, M.; Serio, M.; Potenza, M. A.; Mansi, G.; Salvia, M. A.; Cagiano, R.; et al. Prenatal exposure to carbon monoxide and vascular responsiveness of rat resistance vessels. Life Sci., 59(18):1553-61, 1996.

Montemurro, D. G. \& Bruni, J. E. The Human brain in dissection. $2^{\text {nd }}$ ed. New York, Oxford University Press, 1988. pp.26-8.

Moore, K. L. Blood supply of the cerebellum. Clinically oriented Anatomy. $3^{\text {rd }}$ ed. Baltimore, Williams \& Wilkins, 1985. pp 699700 .

Moore, K. L. \& Persaud, T. V .N. The Developing Human - Clinically Oriented Embryology. An HBJ. International Edition. Saunders, 1998. pp.385-98. 
Neuberger, M.; Endler, M. \& Resch, W. Carbon monoxide in mother and newborn infant from smoking during pregnancy. Zentralbl. Bakteriol. Mikrobiol. Hyg. B, 176(4):349-53, 1982.

Ney, G. C.; Lantos, G.; Barr, W. B. \& Schaul, N. Cerebellar atrophy in patients with long-term phenytoin exposure and epilepsy. Arch. Neurol., 51(8):767-71, 1994.

Ornoy, A. The impact of intrauterine exposure versus postnatal environment in neurodevelopment toxicity: long term neurobehavioral studies in children at risk for developmental disorders. Toxicol. Lett., 140-1:171-81, 2003.

Palay, S. L. \& Chan-Palay, V. Cerebellar cortex: Cytology and organization. New York, Springer Publ., 1974.

Patel, M. N.; Ardelt, B. K.; Yim, G. K. \& Isom, G. E. Cyanide induces calcium ion-dependent and independent release of glutamate from mouse brain slices. Neurosci. Lett., 13(1):42-4, 1991.

Pavlakovic, G.; Rathinavelu, A. \& Isom, G. E. MK-801 prevents cyanide-induced changes of Fos levels in rat brain. Neurochem. Res., 19(10):1289-94, 1994.

Pier-Giorgio, P. Flavonoids as antioxidants. J. Nat. Prod., 63(7):103542, 2000.

Rakic, P. \& Sidman, R. L. Histogenesis of cortical layers in human cerebellum particularly the lamina dissecans. J. Comp. Neurol., 139(4):473-500, 1970.

Roebuck, T. M.; Mattson, S. N. \& Riley, E. P. A review of the neuroanatomical findings in children with fetal alcohol syndrome or prenatal exposure to alcohol. Alcohol. Clin. Exp. Res., 22(2):33944, 1998.

Salah, N.; Miller, N. J.; Paganga, G.; Tijburg, L.; Bolwell, G. P. \& Rice-Evans, C. Polyphenolic flavanols as scavengers of aqueous phase radicals and as chain-breaking antioxidants. Arch. Biochem. Biophys., 322(2):339-46, 1995.

Serafini, M.; Bellocco, R.; Wolk, A. \& Ekström, A. M. Total antioxidant potential of fruit and vegetables and risk of gastric cancer. Gastroenterology, 123(4):985-91, 2002.

Shila, S.; Kokilavani, V.; Subathra, M. \& Panneerselvam, C. Brain regional responses in antioxidant system to alpha-lipoic acid in arsenic intoxicated rat. Toxicology, 210(1):25-36, 2005.

Sies, H. Biochemistry of oxidative stress. Angew. Chem. Int. Ed. Engl., 25:1058-71, 1986.

Siler-Marsiglio, K. L.; Pan, Q.; Paiva, M.; Madorsky, I.; Khurana, N. C. \& Heaton, M. B. Mitochondrially targeted vitamin E and vitamin E mitigate ethanol-mediated effects on cerebellar granule cell antioxidant defense system. Brain Res., 1052(2):202-11, 2005.

Singh, I. Textbook of Human Neuroanatomy. $5^{\text {th }}$ ed. New Delhi, Jaypee Brothers Medical Publishers Limited India, 1997. pp.142-62.

Síngh, S.; Kar, A. K. \& Sanyal, A. K. Prenatal retardation of brain growth of chick embryos following cyclophosphamide administration. Neurol. India, 21(3):104-12, 1973.

Storm, J. E. \& Fechter, L. D. Alteration in the postnatal ontogeny of cerebellar norepinephrine content following chronic prenatal carbon monoxide. J. Neurochem., 45(3):965-9, 1985.

Storm, J. E.; Valdes, J. J. \& Fechter, L. D. Postnatal alterations in cerebellar GABA content, GABA uptake and morphology following exposure to carbon monoxide early in development. Dev. Neurosci., 8(4):251-61, 1986.

Szot, P.; Dodson, R. A. \& Johnson, W. E. Effects of certain CNS depressants and verapamil on cGMP in the cerebellum of rats. Res. Commun. Chem. Pathol. Pharmacol., 50(2):309-12, 1985.

Wang, V. Y. \& Zoghbi, H. Y. Genetic regulation of cerebellar development. Nat. Rev. Neurosci., 2(7):484-91, 2001.

Wayner, D. D.; Burton, G. W.; Ingold, K. U.; Barclay, L. R. \& Locke, S. J. The relative contributions of vitamin E, urate, ascorbate and proteins to the total peroxyl radical-trapping antioxidant activity of human blood plasma. Biochim. Biophys. Acta, 924(3):408-19, 1987.

Wei, T.; Ni, Y.; Hou, J.; Chen, C.; Zhao, B. \& Xin, W. Hydrogen peroxide-induced oxidative damage and apoptosis in cerebellar granule cells: protection by Ginkgo biloba extract. Pharmacol. Res., 41(4):427-33, 2000.

West, J. R.; Goodlett, C. R.; Bonthius, D. J.; Hamre, K. M. \& Marcussen, B. L. Cell population depletion associated with fetal alcohol brain damage: mechanisms of BAC-dependent cell loss. Alcohol. Clin. Exp. Res., 14(6):813-8, 1990.

Williams, P. L.; Warwick, R.; Dyson, M. \& Bannister, L. H. Gray's Anatomy. $37^{\text {th }}$ International Student Edition. London, Churchill Livingstone, 1989. p.188.

Wilkinson, J. M. \& Pollard, I. Accumulation of theophylline, theobromine and paraxanthine in the fetal rat brain following a single oral dose of caffeine. Brain Res. Dev. Brain Res., 75(2):1939, 1993.

Zablocka, A. \& Janusz, M. The two faces of reacting oxygen species. Postepy. Hig. Med. Dosw., 62:118-24, 2008.

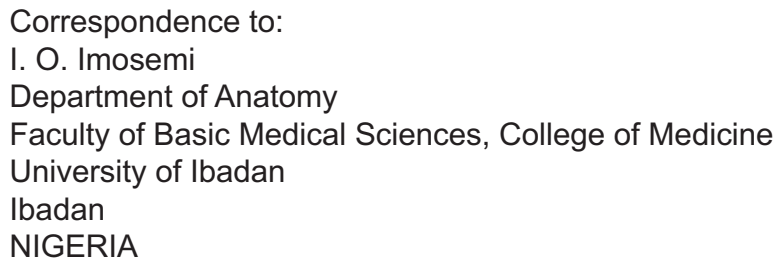

Email: innosemi@yahoo.co.uk

Received: 13-02-2012

Accepted: 03-09-2012 